\title{
A Simple Analysis of the "Departmental benefits" Problem with Administrative System Reform in China
}

\author{
Chenyuan Weng ${ }^{1, a}$ \\ ${ }^{1}$ Public Administration, Hainan University, Hainan 571737, China \\ a505500548@qq.com
}

\begin{abstract}
Keywords: Administrative; system reform; departmental benefits; problem; countermeasure Abstract. In the process of accelerating management system reform, the existence of the "departmental benefits" problem severely impedes the process of reform and provides soil for the survival of corruption behaviors, which not only hinders the construction of public administration system, but also brings resistance to the stable development of socialist construction. For this reason, how to enact countermeasures against the "departmental benefits" problem with current administrative system reform in China has become a big problem and challenge in the administrative transformation process of China. On this basis, this paper analyzes the "departmental interests" problem with administrative system and puts forward a series of countermeasures.
\end{abstract}

\section{Introduction}

In the study of administrative system reform in China, the government power presents a close correlation with "departmental benefits". Also, it is precisely because of this relationship that the current public administrative reform in China is frustrated. The cause of this problem is that for a long time, the departmental power of Chinese government is centralized. As a result, the enactment and implementation of policy make power override common people and further directly harm public interests. Accordingly, contradictions and problems stand out. When promoting the construction of a harmonious socialist society comprehensively, it is of practical significance to solve the “departmental benefits” problem with administrative system reform in China.

\section{The Nature and Social Harm of "Departmental benefits"}

\section{Nature}

The nature of "departmental benefits" is mainly manifested in the following aspects: first of all, it is centered on individual interests and deviates from the category of legitimate interests. Government departments undertake the responsibility of serving people, so public interests must be put in the first place. While departmental benefits are in the disguise of public interests, in order to cover up the pursuit and implementation of individual interests and thus produce corruption behaviors. Secondly, it takes public power as the media. The foundation for the realization of departmental benefits is that administrative departments have public power and are able to provide channels to meet personal interests with the aid of this power. In this process, when personal interests infringe on the interests of others, legal means must be taken to solve these problems. But invalid regulation may provide a loophole to exploit for the realization of "departmental benefits".

Social harm

It is mainly manifested in the following aspects: first of all, departmental benefits bring resistance to administrative transformation. In actual administrative reform, individual interests under departmental benefits conflict with collective interests. In order to realize personal interests, some people are reluctant to relinquish power. Under this circumstance, the vision of public administrative reform is hard to come true due to the presence of resistance. Secondly, the economic operation costs increase, while the administrative efficiency is low. The realization of "departmental benefits" must be based on the use of government resources, including capital and power, etc. Under this circumstance, policies catering to social public interests cannot be implemented. Even if 
corresponding policies are enacted, they will be frustrated in actual implementation. While departmental benefits need to be realized with management and law enforcement power. In this process, economic operation costs will increase, while corresponding administrative efficiency will be low.

\section{The Causes of “Departmental Benefits" Problem with Current Administrative System Reform in China}

The duty separation of administrative departments is ambiguous

Under the long-term bondage of planned economy system, when duties of the administrative system are separated, a strip and block pattern is formed. In this case, in actual operation, domestic administrative institutions lack a longitudinal relevance. The practical operation of each department is isolated and weakens the overall function and effect of administrative departments. In actual management, each department is characterized by obvious centralism. Consequently, industrial monopoly is inevitable in the market. Under the background of deepened reform and opening-up, the development of market economy drives some administrative departments to expand their authority by virtue of diversified interest subjects, to satisfy their own benefits. Meanwhile, under existing administrative laws, administrative departments are independent administrative subjects on the basis of a legal person status. However, some administrative departments deviate when interpreting this rule, enforce the law principally to realize departmental benefits and ignore their essential attributes.

The shift of government function is not complete and the financial system is not sound

On the one hand, the shift of government functions. At present, when administrative system reform is practiced, a series of achievements have been made. But from the specific performance of government in microeconomic activities, we can still see government intervention. The government still takes the initiative in many important matters, such as the appointment and dismissal of corporate leadership. Especially under the influence of departmental benefits, enterprise and public institution reforms are not thorough. Many departments pursue departmental benefits, so that it is hard to eradicate the confusion between government and enterprises and between government affairs. The government function cannot be effectively transformed. On the other hand, the financial system is not sound. This problem can be traced back to the early reform and opening up in China. In order to achieve the success of reform, the government has its financial burden increased when delegating power. In order to solve financial problems, for a time, new departments increase financial income by collecting fees and fines. In this case, corresponding fund-raising mechanism provides soil for the realization of departmental benefits. Again, the construction of a public financial system jogs along. The power, responsibility and interest are not unified. Consequently, departmental benefits aggrandize under the guise of public services and satisfy the demand of departmental benefits with paid services. Especially under the background of unsound government budgets, the budget information is not transparent, making it difficult to realize effective supervision.

\section{Countermeasures to Solve the "Departmental Benefits" Problem with Administrative System Reform Effectively}

To further accelerate the transformation to public administration

In fact, the root of departmental benefits is constraint of administrative system in China. Although in the process of establishing a socialist market economic system, this system did realize development, the constraint of traditional planned economic system has not been completely and thoroughly eliminated. From the perspective of government function, it still intervenes in economy. It is difficult for macro regulation and control to work effectively. Therefore, the operation of market economic system is defective. A typical phenomenon is that the government and enterprise, as well as government affairs are confused. On the other hand, in the setting of administrative departments, the existence of a small department system not only weakens the overall function of government, but also breeds corruption. Moreover, in the operation mechanism of power, inconsistent group interests 
make departmental benefits seriously infringe on public interests for most of the time. While the poor supervision cannot bring it back on the right track. Behind this series of problems, the current administrative system in China has serious defects. The presence of departmental benefits seriously hinders the transformation from administrative management to public administration. In actual reform, the most scientific method is to realize the effective control of departmental benefits, boost administrative system reform in a double-barreled way, further strengthen institutional construction and promote the transformation to public administration, when practicing administrative reform.

To set up a public financial system based on the shift of government function

On the one hand, with respect to the shift of government function, we must put countermeasures against the government intervention in micro economy into effect and further realize the effective solution of departmental benefits. In actual practice, we need to define the relationship between government and market clearly and lay a foundation for the effective shift of government function from the perspective of approval, management and intervention. On this basis, build a service-oriented government, deepen the reform of state-owned enterprises and public institutions, gradually divest the correlation between government, enterprises and public institutions and promote the effective operation of market economic system. By fully exerting the role of government in macroeconomic regulation and control, make departmental benefits behaviors gradually disappear for lack of soil. On the other hand, build a sound public financial system. In actual practice, we need to make the financial system satisfy the need of service-oriented government and realize the unification of power, responsibility and interest, by establishing "the rule of finance by law". Standardize fee and tax collection behaviors, carry out management by separating incomes from expenses and make it difficult to realize departmental benefits behaviors by exercising power, to solve the benefit orientation of departmental power effectively and further lay a foundation to cope with corruption. Meanwhile, enhance the transparency of financial information, intensify supervision and encourage all levels of society to join in the supervision.

\section{Conclusion}

To sum up, for the "departmental benefits” problem with current administrative system reform in China, to quicken the pace of administrative reform, we must combine with existing problems, accelerate the transformation to public administration and establish a public financial system on the basis of the shift of government function, to solve the departmental benefits problem effectively and lay a foundation to promote the construction of a harmonious socialist society.

\section{References}

[1] Yu-Dong X U, Qiu A L, Liu Y Q, et al. Analysis of administrative system reform issues in new period:based on perspective of interaction with regional economic integration[J]. Journal of Shenyang University of Technology, 2015.

[2] Cheng J. An Empirical Analysis of the Procurator's Attitude to the Reform of Classified Management of Judicial Personnel in China[J]. Chinese Journal of Law, 2015.

[3] Qing-Ping L I. Force Filed Analysis of the Administrative Examination and Approval System Reform in China and Breakthrough Strategies[J]. Journal of Fujian Administration Institute, 2014.

[4] Liang M. Does Super-Department Reform Improve Public Service Performance in China?[J]. Public Management Review, 2014:1-23.

[5] Huang G H, Tang Y F. An Analysis on the Compensation Reform of Collective-Owned Land Expropriation in Mainland China:Based on the Comparison between the Cross-Straits[J]. Journal of Beijing Administrative College, 2016. 